\title{
Evaluation of aquifer vulnerability and the protective capacity in some oil producing communities of western Niger Delta
}

\author{
Edmund Aviedo Atakpo · Elijah Adebowale Ayolabi
}

Published online: 15 October 2008

(c) The Author(s) 2008. This article is published with open access at Springerlink.com

\begin{abstract}
Oil spills have become a major environmental hazard constituting serious social problems in Nigeria, especially in the oil producing communities. The spills contaminate the aquifer if the subsurface layers are not protected. Geoelectric technique of geophysical investigation has been used to evaluate the protective capacity of six oil producing communities: Oleh, Olomoro, Uzere, Afiesere, Ekakpamre and Uvwiamuge in the western Niger Delta. A total of 139 vertical electrical sounding (VES) using the Schlumberger electrode configuration were occupied in these communities. The longitudinal conductance maps delineated areas with poor (<0.1 mho), weak (0.1-0.19 mho), moderate (0.2-0.69 mho) and good protective capacity (0.7-4.9 mho). The study has shown that the protective capacity of most parts of the communities studied is poor with Uvwiamuge and Ekakpamre communities not protected hence the aquifer in these oil producing communities are vulnerable to contamination by hydrocarbon in the event of pollution. Hence proper environmental protection measures have been suggested to safeguard the aquifer from pollution by hydrocarbon in the event of spillage.
\end{abstract}

Keywords Protective capacity ·

Longitudinal conductance contamination

\section{Introduction}

The Niger Delta region is endowed with abundant oil and gas deposits which is the backbone of the Nigerian

E. A. Atakpo $(\bowtie) \cdot$ E. A. Ayolabi

Department of Physics, Geophysics Unit, University of Lagos, Akoka, Nigeria

e-mail: e_atakpo@yahoo.com economy, contributing about $90 \%$ of the nation's foreign exchange earning and about $25 \%$ of the GDP. Oil spillage is the major environmental hazard caused by crude oil exploration in the Niger Delta constituting serious social problems in Nigeria, especially in the oil producing communities. Oil spills can occur due to a variety of reasons (Ozumba et al. 1999), including blowouts due to overpressure; equipment failure; operators errors; corrosion; sabotage (vandalisation of pipelines); pigging operations; flowline replacement; flowstation upgrades; tank rehabilitation and natural phenomena such as heavy rainfall, flooding, falling of trees and lightening.

According to Directorate of Petroleum Resources (DPR 1997), over 6,000 spills had been recorded in the 40 years of oil exploitation in Nigeria, with an average of 150 per annum. In the period 1976-1996, 647 incidents occurred resulting in the spillage of 2,369,407.04 barrels of crude oil. With only $549,060.38$ barrels recovered, $1,820,410.50$ barrels were lost to the ecosystem. Similar report by Shell Petroleum Development Company (SPDC 2004) revealed that the company experienced a total of 457 number of oil spills in 2003 and 2004 in which a total of 18,219 barrels of oil were spilled. Pollution due to oil well blowout, corrosion of pipeline and vandalisation can lead to underground leakages which have an impact the environment in the form of groundwater pollution, soil pollution and destruction of vegetation. This may have a more direct impact on man if the subsurface pollution is not noticed on the surface but percolates to the aquifer which is an important source of potable water. The pollution of soil poses serious problems because it may take years for contaminated water to be flushed from an aquifer and replaced with clean water (Pipkin 1994).

As far as exploitation, production and transportation continue, oil producing communities will continue to face 
the consequent environmental effects such as pollution of the subsurface aquifer hence the need to have a picture of the subsurface protective capacity using geophysical methods. Geophysics is an effective non-invasive method that can be used to investigate the protective capacity. Henriet (1976) showed that the combination of layer resistivity and thickness in the Dar Zarrouk parameters $S$ (longitudinal conductance) and $T$ (transverse resistance) may be of direct use in aquifer protection studies, and for the evaluation of hydrologic properties of aquifers also the protective capacity of a clayey aquifer overburden is proportional to its longitudinal unit conductance $S$ which, in terms of aquifer protection, gets a dimension of time (e.g. infiltration time). The protective capacity is considered to be proportional to the longitudinal unit conductance in mho. (Olorunfemi et al. 1998; Oladapo et al. 2004; Ayolabi (2005).

The area of study comprises six oil producing communities (Oleh, Olomoro, Uzere, Afiesere Ekakpamre and Uvwiamuge communities) rich in hydrocarbon deposits. These communities have over 200 producing oil wells, and four flowstations and many pipelines crisscrossing the area. The communities at one time or the other have experienced major oil spillage which destroyed plants and aquatic life thereby affecting the ecosystem and possibly the groundwater (Amaize 2006). This study is therefore, aimed at determining the protective capacity of these areas.

\section{Geomorphology and geology of the study area}

The study areas (Oleh, Olomoro, Uzere, Afiesere, Ekakpamre and Uvwiamuge communities) are located in
Isoko South, Ughelli North and Ughelli South Local Government areas of Delta State. They lie within longitude $5^{\circ} 52^{\prime}$ and $6^{\circ} 20^{\prime}$ East and latitude $5^{\circ} 15^{\prime}$ and $5^{\circ} 40^{\prime}$ North of the equator (Fig. 1) and average elevation of about $10 \mathrm{~m}$ above the sea level. The area under study falls within the Niger Delta which is characterised by nearly flat topography sloping very slightly seawards (Akpokodje and EtuEfeotor 1987) and underlain by the quaternary sands of the Sombrero plain. This area lies in the sedimentary basin and is devoid of any outcrop. During the rainy season, the area is flooded while it is dry during dry season. Some parts of the areas are swampy. The vegetation of the areas is typical of the rainforest belt except along drainage stream where swampy areas exist as typical of the Niger Delta region.

The geologic sequence of the Niger Delta consists of three main tertiary subsurface lithostratigraphic units which are overlain by various types of quaternary deposits (Short and Stauble 1967). The base of the unit is the Akata formation and it comprise mainly of marine shales with some sand beds. The formation ranges in thickness from about 550 to over $6,000 \mathrm{~m}$. Very little hydrocarbon has been associated with the formation. The Agbada formation is the overlying paralic sequence which consists of interbedded sands and shale with a thickness of 300 up to about $4,500 \mathrm{~m}$, thinning both seawards and towards the Delta margin. The top most unit is the Benin formation. It is over $90 \%$ sandstone with shale intercalations. It is coarse grained, gravely, locally fine grained, poorly sorted, subangular to well rounded and bears lignite streaks and wood fragments (Asseez 1989). The unit is thickest in the central area of the Delta. The contact with the underlying Agbada formation is defined by the base of sandstones which also corresponds to the base of the fresh water bearing strata.
Fig. 1 Delta state showing the study area

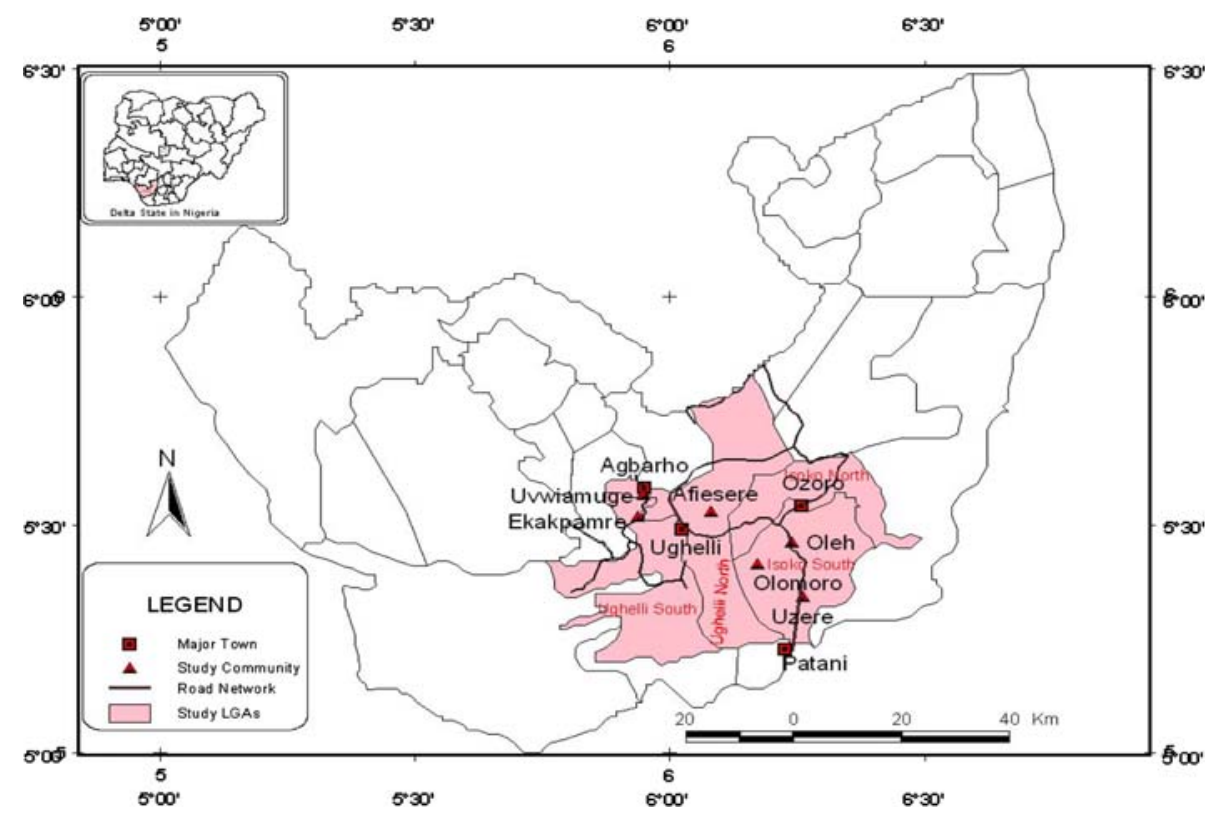


Fig. 2 a Data acquisition map of Olomoro. b Data acquisition map of Afiesere

\section{Methodology}

The ABEM signal averaging system Terrameter (1000) model was used for the resistivity data acquisition. It is very portable to use and has high signal-to-noise ratio and an inbuilt booster for greater depth of penetration.

The Schlumberger depth sounding technique which is most preferred because of its sensitivity to surface inhomogeneities was adopted for the data acquisition
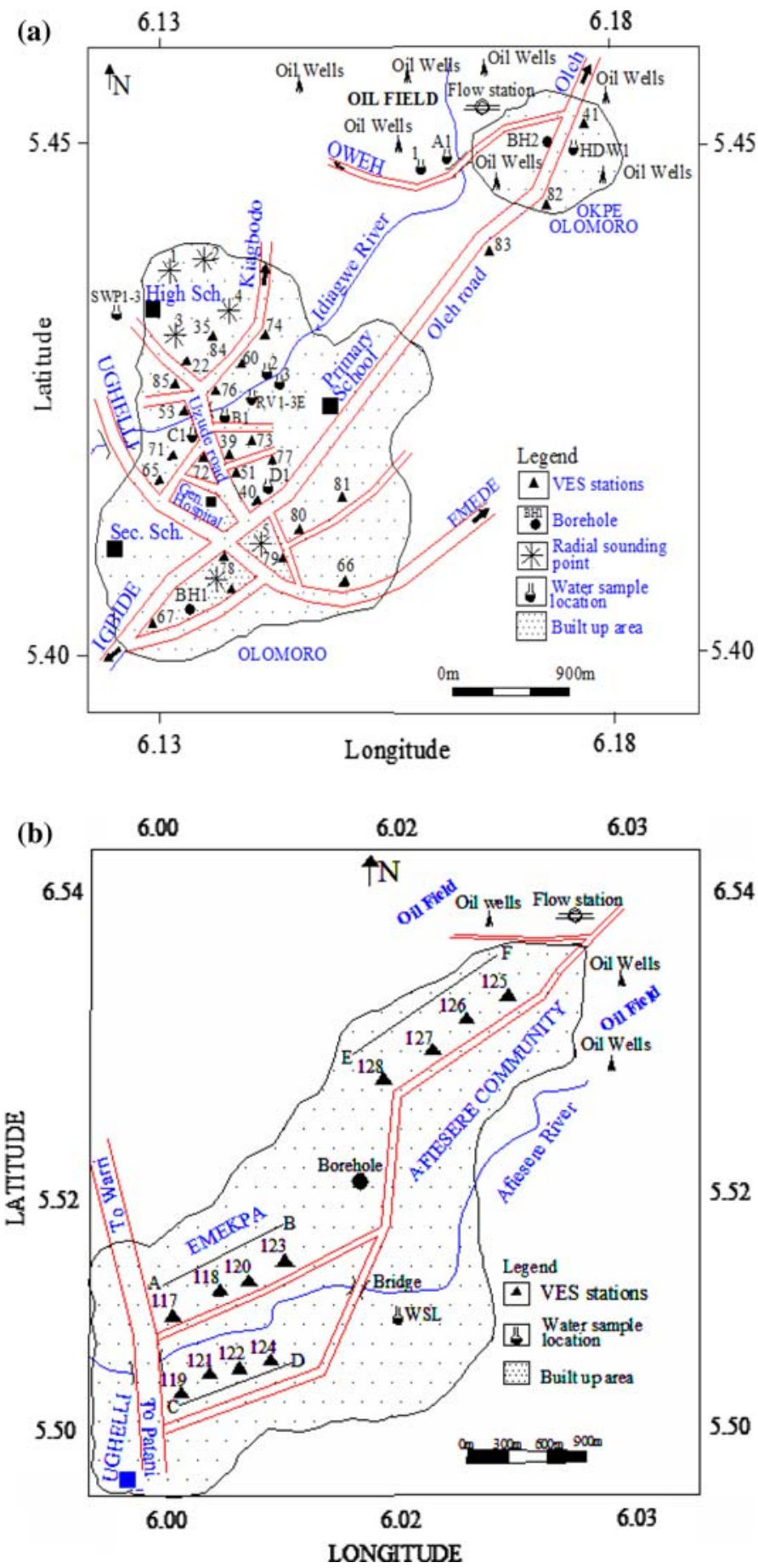

(Sharma Prem 1997; Afolabi et al. 2004). This method delineates contaminated zones of groundwater, capable of clarifying subsurface structure distinctly, adequate depth of penetration and it requires less labour. In this study the maximum electrode separation varied from $50 \mathrm{~m}$ to $1,000 \mathrm{~m}$ in order to obtain shallow, deep and very deep sounding.

A total of 139 vertical electrical sounding (VES) were carried out in the six communities: twenty one VES 
stations were occupied in Oleh, sixty four in Okpe Olomoro and Olomoro communities, thirty one in Uzere, twelve in Afiesere, three in Ekakpamre and eight in Uvwiamuge communities. The location of the VES in Olomoro, Afiesere are shown in the data acquisition maps (Fig. 2a, b).

The VES data obtained from the electrical resistivity survey are presented as VES curves (Fig. 3). The VES curves were interpreted quantitatively by computer iteration using the Resist Software based on the work of Vander Velpen 1988 to obtain the first-order geoelectric parameters (the layer resistivity $\rho_{\mathrm{i}}$ and the layer thickness $h_{i}$, (Table 1 ) for the ith layer ( $i=1$ for the surface layer).

These first-order geoelectric parameters were utilised in deriving the longitudinal unit conductance $\left(S_{i}\right)$, which is a second-order geoelectric parameter or the Dar Zarrouk parameter (Maillet 1947).

The total longitudinal unit conductance

$S=\sum_{i=1}^{n} \frac{h_{i}}{\rho_{i}}$

The overburden protective capacity in an area was evaluated by utilising the total longitudinal unit conductance values of Eq. 1 (Henriet 1976; Oladapo et al. 2004).

Table 1 shows the longitudinal conductance values of the study area.

\section{Results and discussion}

The longitudinal conductance values were used to generate protective capacity maps with the aid of SURFER 8 Terrain and 3D Surface modeling software (2002). The protective capacity was interpreted based on the modified (Oladapo et al. 2004) longitudinal conductance/protective capacity rating in Table 2 .

\section{Longitudinal unit conductance maps}

The longitudinal conductance maps showing the overburden protective capacity of the six communities are shown in Fig. 4. The red colour depicts areas with poor protective capacity having longitudinal conductance of $<0.1 \mathrm{mho}$, the green colour depicts areas with weak protective capacity having longitudinal conductance of 0.1-0.19 mho, the yellow colour depicts areas with moderate protective capacity having longitudinal conductance value of $0.2-0.69$ mho and the blue colour for areas with good protective capacity with longitudinal conductance values of 0.7-4.9 mho.

\section{Protective capacity of study areas}

The longitudinal conductance map showing the overburden protective capacity of Oleh is shown in Fig. 4a. The poor
Fig. 3 Computer iterated field curves

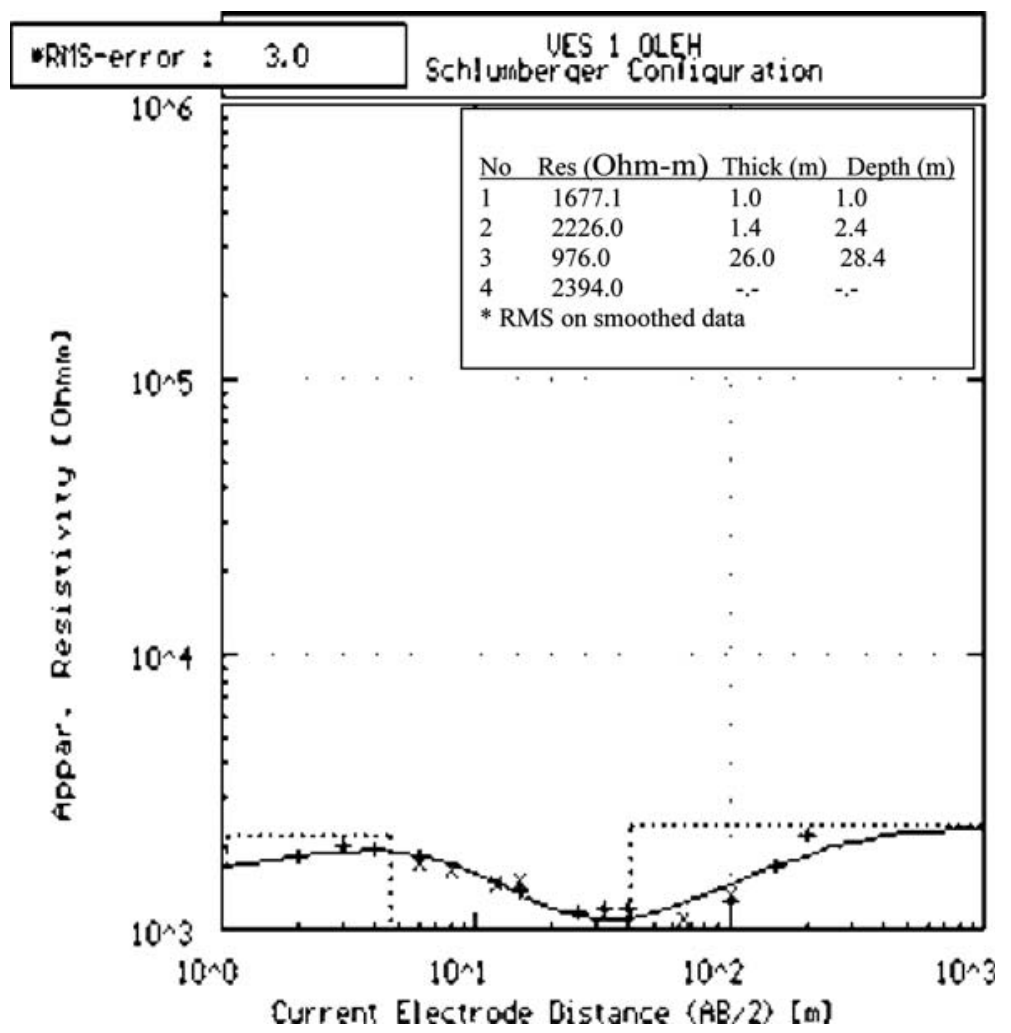


Table 1 VES interpreted results and longitudinal conductance values

\begin{tabular}{|c|c|c|c|c|c|c|c|}
\hline VES stn. & $\begin{array}{l}\text { Resistivity } \\
\left(h_{1} / h_{2} / h_{3} / \ldots / h_{\mathrm{n}}\right)\end{array}$ & $\begin{array}{l}\text { Thickness } \\
\left(\rho_{1} / \rho_{2} / \rho_{3} / \ldots / \rho_{\mathrm{n}}\right)\end{array}$ & $S=\sum_{i=1}^{n} \frac{h_{i}}{\rho_{i}}$ & VES stn. & $\begin{array}{l}\text { Resistivity } \\
\left(h_{1} / h_{2} / h_{3} / \ldots / h_{\mathrm{n}}\right)\end{array}$ & $\begin{array}{l}\text { Thickness } \\
\left(\rho_{1} / \rho_{2} / \rho_{3} / \ldots / \rho_{\mathrm{n}}\right)\end{array}$ & $S=\sum_{i=1}^{n} \frac{h_{i}}{\rho_{i}}$ \\
\hline Oleh & & & & 48 & $510 / 342$ & $0.9 / 4.3$ & 0.01144 \\
\hline 1 & $1677 / 2227 / 97$ & $1 / 3.6 / 36.4 \ldots \ldots$ & 0.03759 & 49 & $579 / 415$ & $0.9 / 5.1$ & 0.01405 \\
\hline 2 & $1709 / 2416 / 964 / 2338$ & $1 / 2.1 / 7.2 / 87$ & 1.00146 & 50 & $385 / 121 / 27$ & $0.9 / 3.8 .15$ & 0.615 \\
\hline 3 & $383 / 1065 / 444$ & $0.9 / 6.7 / 42.2$ & 0.0087 & 51 & $443 / 53 / 125$ & $1.1 / 6.1 / 6.9$ & 0.2523 \\
\hline 4 & $274 / 615 / 134$ & $0.8 / 1.9 / 18.5$ & 0.146 & 52 & $70 / 14 / 86$ & $0.7 / 3.1 / 10.1$ & 0.397 \\
\hline 5 & $137 / 24 / 428$ & $1.5 / 11.6 / 29.4$ & 0.49 & 53 & $1377 / 1029 / 1368$ & $1 / 4.2 / 20.8$ & 0.0114 \\
\hline 6 & $23 / 644 / 95$ & $0.5 / 4.7 / 12.7$ & 0.163 & 54 & $3399 / 4483$ & $1.0 / 7.4$ & 0.0046 \\
\hline 7 & $1525 / 1484$ & $1.7 / 14.4$ & 0.0097 & 55 & $2800 / 7587$ & $1.1 / 10.2$ & 0.0052 \\
\hline 8 & $233 / 629 / 215 / 805 / 278$ & $1.1 / 6 / 9.2 / 38 / 52$ & 0.0573 & 56 & $3684 / 57278$ & $1.0 / 11.4$ & 0.00476 \\
\hline 9 & $426 / 2653$ & $0.9 / 16.5$ & 0.08 & 57 & $2092 / 5493$ & $1.0 / 7.8$ & 0.00188 \\
\hline 10 & $403 / 1163$ & $0.8 / 8.1$ & 0.09 & 58 & $2000 / 3014$ & $1.0 / 15.0$ & 0.0085 \\
\hline 11 & $535 / 245$ & $1.7 / 12.0$ & 0.502 & 59 & $1257 / 361 / 2441$ & $0.7 / 3.8 / 19.2$ & 0.01156 \\
\hline 12 & $467 / 51$ & $1.8 / 8.4$ & 0.1679 & 60 & $3780 / 1573 / 3807$ & $1.3 / 7.8 / 23.9$ & 0.00521 \\
\hline 13 & $153 / 1018 / 403$ & $0.6 / 2.1 / 30$ & 0.0060 & 61 & $1043 / 1151$ & $1.0 / 9.4$ & 0.00916 \\
\hline 14 & $150 / 35$ & $1.9 / 9.4$ & 0.283 & 62 & $1213 / 926 / 2451$ & $1.0 / 3.3 / 23.4$ & 0.00442 \\
\hline 15 & $998 / 3217 / 2421$ & $1.6 / 4.3 / 29.8$ & 0.0029 & 63 & $1271 / 985 / 2510$ & $1.0 / 4.0 / 20.4$ & 0.00489 \\
\hline 16 & $55 / 22 / 112$ & $2.1 / 6 / 14.9$ & 0.444 & 64 & $1577 / 814 / 2776$ & $1.1 / 6.0 / 19.2$ & 0.00810 \\
\hline 17 & $54 / 200 / 46$ & $0.9 / 4 / 14$ & 0.339 & 65 & $945 / 617 / 1744$ & $1.2 / 2.7 / 36.7$ & 0.00567 \\
\hline 18 & $110 / 537 / 184$ & $0.9 / 12.5 / 35.5$ & 0.0312 & 66 & $310 / 939 / 152 / 1402 / 621$ & $0.6 / 1.0 / 3.6 / 50.4 / 64$ & 0.02674 \\
\hline 19 & $129 / 312 / 165$ & $0.9 / 5.8 / 18.5$ & 0.1375 & 67 & $178 / 1439 / 327 / 2491$ & $0.5 / 2.0 / 4.7 / 38.7$ & 0.00419 \\
\hline 20 & $78 / 54 / 231$ & $1.9 / 34.6$ & 0.665 & 68 & $58 / 80 / 326$ & $1.0 / 6.1 / 28.9$ & 0.0935 \\
\hline 21 & $75 / 170 / 404$ & $1.5 / 33$ & 0.214 & 69 & $325 / 140 / 837 / 318$ & $0.6 / 2.0 / 34 / 44$ & 0.16 \\
\hline Olomoro & & & & 70 & $97 / 189 / 672 / 362$ & $1.0 / 4.8 / 32 / 48$ & 0.036 \\
\hline 22 & $1614 / 862 / 2201 / 1121$ & $0.9 / 4.8 / 30.6 / 104$ & 0.0112 & 71 & $44 / 239$ & $1.4 / 11.3$ & 0.079 \\
\hline 23 & $5370 / 2857$ & $1.6 / 8.8$ & 0.0034 & 72 & $365 / 204 / 44$ & $0.8 / 1.9 / 16.7$ & 0.37 \\
\hline 24 & $6004 / 1844$ & $2.6 / 8.9$ & 0.00523 & 73 & $53 / 48$ & $1.7 / 19.3$ & 0.425 \\
\hline 25 & $5812 / 2797$ & $1.9 / 5.3$ & 0.00223 & 74 & $2147714 / 2791$ & $0.9 / 4.5 / 76$ & 0.00672 \\
\hline 26 & $5916 / 2118$ & $2.1 / 9.0$ & 0.00460 & 75 & $3345 / 1334 / 2452$ & $1.2 / 6.6 / 38$ & 0.0053 \\
\hline 27 & $5238 / 2610$ & $1.5 / 7.6$ & 0.00319 & 76 & $109 / 315 / 179$ & $0.6 / 2.3 / 4.7$ & 0.039 \\
\hline 28 & $5867 / 2109$ & $1.9 / 9.0$ & 0.00462 & 77 & $1379 / 448 / 45 / 590$ & $2.0 / 2.3 / 11 / 27$ & 0.253 \\
\hline 29 & $5871 / 2443$ & $2.1 / 8.6$ & 0.00386 & 78 & $58 / 45 / 324$ & $0.9 / 3.4 / 18.1$ & 0.091 \\
\hline 30 & $6515 / 2257$ & $2.1 / 8.8$ & 0.00421 & 79 & $142 / 562 / 193$ & $0.6 / 16.3 / 12.1$ & 0.004 \\
\hline 31 & $1794 / 63$ & $1.7 / 8.9$ & 0.0074 & 80 & $67 / 86 / 469 / 185$ & $11 / 2.6 / 12.6 / 21$ & 0.07 \\
\hline 32 & $1493 / 1420$ & $1.5 / 8.9$ & 0.0073 & 81 & $445 / 261 / 711 / 290$ & $1.7 / 3.4 / 14 / 23$ & 0.0168 \\
\hline 33 & $1841 / 1784$ & $2.1 / 7.4$ & 0.00534 & 82 & $1222 / 922 / 1953 / 900$ & $1.2 / 3.2 / 11.3 / 20.1$ & 0.0045 \\
\hline 34 & $1556 / 1330$ & $2.0 / 9.8$ & 0.0087 & 83 & $1331 / 1299$ & $1.7 / 7.1$ & 0.0068 \\
\hline 35 & $3101 / 1468 / 1875$ & $2.3 / 12.0 / 57$ & 0.0089 & 84 & $299 / 2391$ & $0.9 / 5.2$ & 0.0044 \\
\hline 36 & $2746 / 1484$ & $2.6 / 8.9$ & 0.00685 & 85 & $2684 / 4803$ & $0.8 / 3.8$ & 0.0011 \\
\hline 37 & $2859 / 1367$ & $2.8 / 8.2$ & 0.00698 & Uzere & & & \\
\hline 38 & $2706 / 1574$ & $2.5 / 11.5$ & 0.05792 & 86 & $241 / 874 / 272$ & $0.8 / 4.6 / 11.7$ & 0.00862 \\
\hline 39 & $58 / 515 / 81$ & $0.8 / 7.2 / 27.3$ & 0.365 & 87 & $608 / 287 / 2146$ & $1.4 / 5.1 / 41.7$ & 0.0201 \\
\hline 40 & $267 / 161 / 333$ & $0.8 / 15 / 32.5$ & 0.009 & 88 & $625 / 892 / 4517$ & $1.0 / 3.1 / 25$ & 0.0051 \\
\hline 41 & $173 / 30 / 32$ & $2 / 10.6 / 17.2$ & 0.3646 & 89 & $480 / 953 / 3368$ & $0.8 / 7.1 / 30.4$ & 0.00912 \\
\hline 42 & $345 / 135$ & $0.8 / 3.4$ & 0.0273 & 90 & $428 / 2075 / 4091$ & $1.0 / 3.5 / 18.1$ & 0.004 \\
\hline 43 & $445 / 154$ & $0.6 / 4.1$ & 0.0280 & 91 & $404 / 85 / 19$ & $1.0 / 4.7 / 14.7$ & 1.33 \\
\hline 44 & $501 / 148$ & $0.7 / 4.3$ & 0.0304 & 92 & $155 / 34 / 19$ & $1.9 / 6.1 / 18$ & 1.14 \\
\hline 45 & $331 / 136$ & $0.9 / 4.2$ & 0.0337 & 93 & $87 / 13$ & $0.9 / 15$ & 1.165 \\
\hline 46 & $664 / 386$ & $0.9 / 5.5$ & 0.01568 & 94 & $331 / 17$ & $1.1 / 20.7$ & 1.221 \\
\hline 47 & $584 / 341$ & $0.7 / 4.1$ & 0.0132 & 95 & $2553 / 688 / 7114$ & $2.5 / 8.2 / 56$ & 0.013 \\
\hline
\end{tabular}


Table 1 continued

\begin{tabular}{|c|c|c|c|}
\hline VES stn. & $\begin{array}{l}\text { Resistivity } \\
\left(h_{1} / h_{2} / h_{3} / \ldots / h_{\mathrm{n}}\right)\end{array}$ & $\begin{array}{l}\text { Thickness } \\
\left(\rho_{1} / \rho_{2} / \rho_{3} / \ldots / \rho_{\mathrm{n}}\right)\end{array}$ & $S=\sum_{i=1}^{n} \frac{h}{\rho}$ \\
\hline 96 & $1481 / 434 / 3408$ & $0.8 / 3.4 / 18.6$ & 0.0083 \\
\hline 97 & $787 / 1192 / 3314$ & $1.0 / 6.3 / 26.4$ & 0.0065 \\
\hline 98 & $975 / 1491 / 936 / 2886$ & $0.9 / 3.2 / 5.4 / 17.7$ & 0.0091 \\
\hline 99 & $1105 / 1896 / 2121$ & $0.6 / 3.9 / 25.6$ & 0.00264 \\
\hline 100 & $1259 / 2896 / 2551$ & $0.9 / 4.1 / 41.8$ & 0.0021 \\
\hline 101 & $1290 / 323 / 1189 / 202$ & $1.0 / 3.4 / 16.7 / 40$ & 0.0113 \\
\hline 102 & $1140 / 20 / 74$ & $1.0 / 1.4 / 21.3$ & 0.3587 \\
\hline 103 & $805 / 367 / 737 / 109$ & $1.2 / 5.3 / 8.2 / 16.2$ & 0.01593 \\
\hline 104 & $698 / 210 / 731 / 101$ & $1.7 / 2.9 / 6.6 / 30$ & 0.032 \\
\hline 105 & $677 / 1260 / 2532$ & $0.8 / 5.3 / 34.5$ & 0.0054 \\
\hline 106 & $1383 / 437 / 2144$ & $1.5 / 8.7 / 47.2$ & 0.0210 \\
\hline 107 & $1353 / 599 / 3174$ & $1.1 / 6.2 / 43$ & 0.0112 \\
\hline 108 & 1007/662/1980/937 & $0.9 / 3.5 / 17.5 / 28.4$ & 0.00618 \\
\hline 109 & $1129 / 636 / 3390$ & $1.2 / 3.5 / 32.7$ & 0.0066 \\
\hline 110 & $533 / 2686$ & $0.8 / 11.3$ & 0.0571 \\
\hline 111 & 2300/1497/7957 & $0.8 / 2.3 / 26$ & 0.014 \\
\hline 112 & $1734 / 629 / 1651$ & $0.9 / 2.1 / 8.8$ & 0.00854 \\
\hline 113 & $355 / 1612$ & $1.0 / 13.2$ & 0.01 \\
\hline 114 & $1929 / 1198 / 2835$ & $1.1 / 3.2 / 22.1$ & 0.00324 \\
\hline 115 & $268 / 714$ & $3.0 / 9.5$ & 0.0111 \\
\hline 116 & $2533 / 334 / 655$ & $1.2 / 5.0 / 12.7$ & 0.015 \\
\hline \multicolumn{4}{|l|}{ Afiesere } \\
\hline 117 & $1128 / 1032 / 2722 / 559$ & $0.8 / 1.4 / 5.8 / 23$ & 0.0042 \\
\hline 118 & $1154 / 506$ & $0.9 / 14.1$ & 0.0293 \\
\hline 119 & $49 / 562 / 2759$ & $0.9 / 1.9 / 18.6$ & 0.022 \\
\hline 120 & $62 / 558 / 359$ & $1.3 / 18.7 / 5.2$ & 0.0545 \\
\hline 121 & $41 / 158 / 118$ & $0.8 / 3.3 / 2.4$ & 0.061 \\
\hline 122 & $32 / 247 / 84$ & $0.8 / 2.5 / 4.9$ & 0.093 \\
\hline 123 & $180 / 568 / 965$ & $1.9 / 15.5 / 21.7$ & 0.035 \\
\hline 124 & $45 / 270 / 2413$ & $0.8 / 1.2 / 14.8$ & 0.022 \\
\hline 125 & $74 / 126 / 2003$ & $0.8 / 4.2 / 42$ & 0.043 \\
\hline 126 & $12 / 224 / 61$ & $0.5 / 2.3 / 5.1$ & 0.0136 \\
\hline 127 & $30 / 246 / 80$ & $0.9 / 5.9 / 10.4$ & 0.0184 \\
\hline 128 & $57 / 70 / 627$ & $0.9 / 6.5 / 13.2$ & 0.011 \\
\hline \multicolumn{4}{|c|}{ Ekakpamre } \\
\hline 129 & $37 / 124 / 335$ & $0.9 / 4.7 / 21.9$ & 0.05 \\
\hline 130 & $309 / 983 / 426 / 1539$ & $0.5 / 4.8 / 3.3 / 21$ & 0.0065 \\
\hline 131 & $37 / 124 / 335$ & $0.9 / 4.7 / 22$ & 0.0579 \\
\hline \multicolumn{4}{|c|}{ Uvwiamuge } \\
\hline 132 & $926 / 669 / 1540 / 302$ & $1.0 / 1.4 / 26 / 43$ & 0.0032 \\
\hline 133 & $681 / 198 / 715 / 342$ & $1.3 / 3.6 / 25 / 148$ & 0.02 \\
\hline 134 & $836 / 149 / 1667$ & $0.6 / 3 / 10.7$ & 0.021 \\
\hline 135 & $914 / 196 / 2225 / 471$ & $1.5 / 0.4 / 16 / 58$ & 0.004 \\
\hline 136 & $188 / 395 / 1583$ & $1.3 / 2.8 / 28$ & 0.014 \\
\hline 137 & $78 / 22 / 418 / 947$ & $0.5 / 1.3 / 4.1 / 7.1$ & 0.066 \\
\hline 138 & $103 / 55$ & $0.7 / 2.3$ & 0.055 \\
\hline 139 & $106 / 70$ & $0.7 / 1.6$ & 0.0295 \\
\hline
\end{tabular}

Table 2 Modified the longitudinal conductance/protective capacity rating (Oladapo et al. 2004)

\begin{tabular}{ll}
\hline $\begin{array}{l}\text { Longitudinal conductance } \\
(\mathrm{mho})\end{array}$ & $\begin{array}{l}\text { Protective capacity } \\
\text { rating }\end{array}$ \\
\hline$>10$ & Excellent \\
$5-10$ & Very good \\
$0.7-4.9$ & Good \\
$0.2-0.69$ & Moderate \\
$0.1-0.19$ & Weak \\
$<0.1$ & Poor \\
\hline
\end{tabular}

and weak protective zones are prone to hydrocarbon pollution. The following VES locations fall within the area of poor protective capacity; VES 1, 2, 3, 7, 8, 9, 10, 11, 13 and 15 while VES 4, 12, 19 and 6 are in the weak protective capacity zones. The data acquisition map of Oleh (Fig. 2) shows that VES 8, 9 and 10 are very close to oil wells and pipelines (about $50 \mathrm{~m}$ ), hence the aquifer in this residential area is not protected and is prone to contamination by hydrocarbon. The central part of the community lies in the moderately protected zone; these include VES 5, 20, 14, 17 and 18 . The aquifer in this area is protected from percolating fluid.

The longitudinal conductance map of Olomoro (Fig. 4b) shows that a large extent of the Olomoro is not protected. Only a small area of the community is moderately protected (VES 73, 77, 51, 39, 52, 53 and 41). Hence the aquifer in Olomoro community is prone to contamination in the event of hydrocarbon pollution. A part of the Okpe Olomoro community around VES 82 is also not protected This community stands a higher risk groundwater contamination because oil wells are located less than $10 \mathrm{~m}$ from the community as can be seen from the data acquisition map (Fig. 2).

The longitudinal conductance map of Uzere (Fig. 4c) shows that parts of the Uzere community are protected; VES 91, 92, 93 and 94 are located in areas having good protective capacity zone with longitudinal conductance value between 0.7 and 4.9 mho (blue colour). The areas having poor protective capacity are towards the oil field in the outskirts of the community.

In Afiesere (Fig. 4d) the longitudinal conductance map shows almost the whole of the community is not protected. Apart from VES 112 area which is moderately protected the rest of the area have weak and poor protective capacities thereby exposing the aquifer to contamination in the event of hydrocarbon pollution.

The longitudinal conductance map of Uvwiamuge and Ekakpamre showing the overburden protective capacity is as presented in Fig. 4e. The red colour depicts areas with 
Fig. 4 a Longitudinal conductance maps of Oleh, showing the overburden protective capacity. b Longitudinal conductance maps of Olomoro showing the overburden protective capacity. c Longitudinal conductance maps of Uzere showing the overburden protective capacity. d Longitudinal conductance maps of Afiesere showing the overburden protective capacity. e Longitudinal conductance maps of Ekakpamre and Uvwiamuge showing the overburden protective capacity
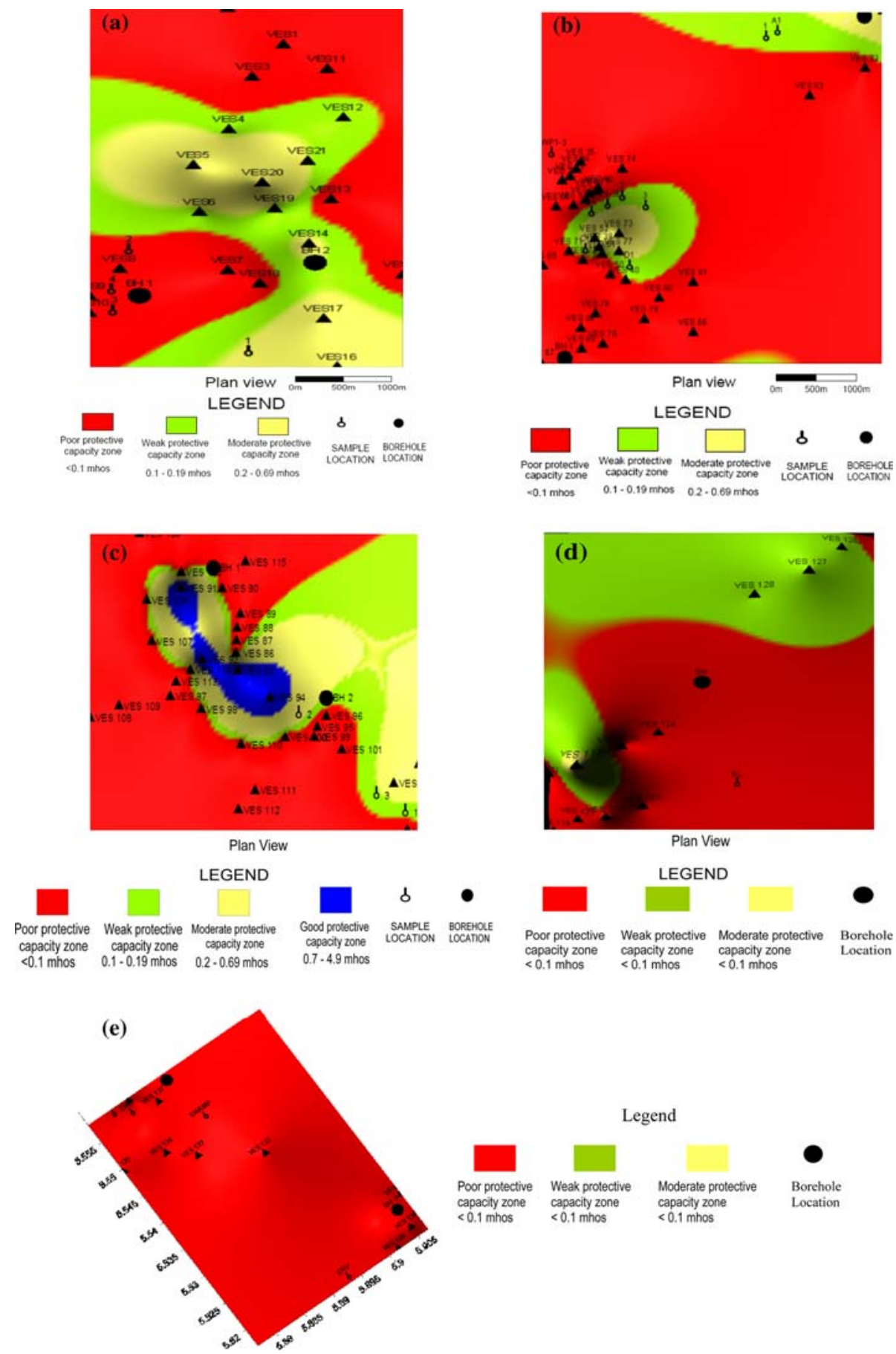

poor protective capacity having longitudinal conductance of $<0.1$ mho. The protective capacity of the whole of Uvwiamuge and Ekakpamre area is poor. The area has very little or no clay and lateritic overburden to protect the aquifer. The Uvwiamuge and Ekakpamre communities are the least protected of the five communities studied and the aquifer most prone to contamination.

\section{Conclusion}

This paper describes the determination of the overburden protective capacity using the electrical resistivity survey. The survey involve a total 139 Schlumberger vertical electrical soundings (VES) distributed in the six communities comprising the survey area. In this study the 
maximum electrode separation varied from 50 to $1000 \mathrm{~m}$ in order to obtain shallow, deep and very deep sounding. The VES data were presented as VES curves interpreted quantitatively by partial curve matching computer iteration using the Resist Software to obtain the first-order geoelectric parameters (the layer resistivity $\rho$ and the layer thickness $h$. These first-order geoelectric parameters were utilised in deriving the longitudinal unit conductance $(S)$. The overburden protective capacity in an area was evaluated by utilising the total longitudinal unit conductance values. The longitudinal conductance maps delineated areas with poor $(<0.1 \mathrm{mho})$, weak $(0.1-0.19 \mathrm{mho})$, moderate (0.2-0.69 mho) and good protective capacity (0.7$4.9 \mathrm{mho}$ ). The protective capacity of most parts of the communities studied is poor with Uvwiamuge and Ekakpamre communities not protected, hence the aquifer in these oil producing communities are prone to contamination by hydrocarbon in the event of pollution. Management of the water quality must be given top priority in these oil producing communities since they experience frequent spillages. Some of the measures that can be taken for the protection of the aquifer include: (i) Drilling deep boreholes in the area and awareness should be created by discouraging the inhabitants from drinking water from hand dug wells which can be easily polluted, (ii) pipelines should be frequently monitored for corrosion and in the event of spillage either by sabotage or otherwise remediation measures should be done immediately to prevent the contamination of the aquifer which is vulnerable, (iii) groundwater monitoring wells should be provided in these communities and constant water quality analysis conducted.

Open Access This article is distributed under the terms of the Creative Commons Attribution Noncommercial License which permits any noncommercial use, distribution, and reproduction in any medium, provided the original author(s) and source are credited.

\section{References}

Afolabi O, Olorunfemi MO, Afolayan JF (2004) Resource quantification of kaolin deposit using the electrical resistivity method-case study from Ikere Ekiti, Southwest, Nigeria, Ife. J Sci 6(1):35-40

Akpokodje EG, Etu-Efeotor JO (1987) The occurrence and economic potential of clean sand deposits of the Niger Delta. J Afr Earth Sci 6(1):61-65

Amaize E (2006) Oil spill in Olomoro destroys aquatic life and economic crops. Vanguard Newspaper, 13th September: 20

Asseez OL (1989) Review of the stratigraphy, sedimentation and structure of the Niger Delta. In: Kogbe (ed) Geology of Nigeria, Rock View (Nig.) Ltd., Jos, pp 311-324

Ayolabi EA (2005) Geoelectric evaluation of Olushosun landfill site Southwest Nigeria and its implication on groundwater. J Geol Soc India 66:318-322

DPR (1997) Annual reports. Department of Petroleum Resources, Abuja. p 191

Henriet JP (1976) Direct application of the Dar Zarrouk parameters in groundwater surveys. Geophys Prospect 24:344-353

Maillet R (1947) The fundamental equations of electrical prospecting. Geophysics 12:527-556

Oladapo MI, Mohammed MZ, Adeoye OO, Adetola BA (2004) Geoelectrical investigation of the Ondo State Housing Corporation Estate, Ijapo Akure, Southwestern Nigeria. J Min Geol 40(1):41-48

Olorunfemi MO, Ojo JS, Oladapo MI (1998) Geological, hydrogeological and geophysical investigation of exposed 20" Escravos Lagos Pipeline. Technical report

Ozumba CI, Ozumba MB, Obobaifo CE (1999) Striking a balance between oil exploration and protecting the environment. NAPE Bull 14(2):130-135

Pipkin BW (1994) Geology and environment. West publishing Company, USA, p 476

Sharma Prem V (1997) Environmental and engineering geophysics. Cambridge University Press, Cambridge, p 475

Short KC, Stauble AJ (1967) Outline of geology of Niger Delta. AAPG Bull 51:761-779

SPDC (2004) People and the environment. Annual report. The Shell Development Company of Nigeria Ltd., p 47

Surfer (2002) Contouring and 3D surface mapping for scientists and engineers. Golden software Incorporation, Colorado, USA

Vander Velpen. BPA (1988) RESIST version 1.0. M. Sc Research Project. ITC, Deft, Netherlands 